OPEN ACCESS

Edited by:

Shripad T. Revankar,

Purdue University, United States

Reviewed by:

Donny Hartanto,

University of Sharjah, United Arab

Emirates

Ayhan Kara,

Giresun University, Turkey

*Correspondence:

Mehtap Düz

mehtap.gunay@inonu.edu.tr

${ }^{+}$ORCID:

orcid.org/0000-0002-0445-1648

Specialty section: This article was submitted to

Nuclear Energy,

a section of the journal

Frontiers in Energy Research

Received: 08 December 2020

Accepted: 21 January 2021

Published: 05 March 2021

Citation:

Düz M (2021) Neutronic Calculations for Certain Americium Mixed Fuels and

Clads in a Boiling Water Reactor.

Front. Energy Res. 9:639416.

doi: 10.3389/fenrg.2021.639416

\section{Neutronic Calculations for Certain Americium Mixed Fuels and Clads in a Boiling Water Reactor}

\author{
Mehtap Düz *t \\ Department of Physics, Faculty of Arts and Sciences, Inönü University, Malatya, Turkey
}

In this study, a Boiling Water Reactor (BWR) design was made using the Monte Carlo (MCNPX) method. The reactor core in the designed BWR system was divided into an $8 \times 8$ square lattice with a constant pitch of $30.48 \mathrm{~cm}$. In this study, americium (Am), which is found in the minor actinidine (MA) of spent nuclear fuel known as nuclear waste from existing reactors, was used as fuel with the addition of oxygen and fluorine. In this study, $\mathrm{AmO}_{2}$ and $\mathrm{AmF}_{3}$ fuels at the rate of $0.02-0.1 \%$ were used as Americium Mixed Fuels, and Zircaloy-2 (Zr-2), SiC, and VC were used as clad. Neutronic calculations for certain Americium Mixed Fuels and clads were compared in the designed BWR system. In

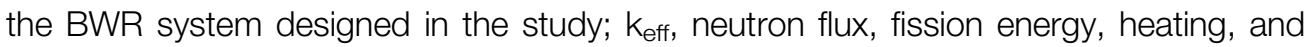
depleted Am were calculated. The three-dimensional (3-D) modeling of the designed BWR system was performed by using MCNPX-2.7.0 Monte Carlo method and the ENDF/B-VII.0 nuclear data library.

Keywords: boiling water reactor, keff, neutron flux, fission energy, heating, MCNPX-2.7.0

\section{INTRODUCTION}

BWR is a type of light water reactor (LWR) from the fission reactors used today. BWR uses water as a coolant for electric energy production and fissile fuel as a fuel. Today, fission reactors generally use ${ }^{235} \mathrm{U}$ fuel enriched with $2-5 \%$. Current fission reactors around the world consume about 60,000 tons of uranium per year (Doligez et al., 2017). Considering that there are nuclear reactors available in different parts of the world, it is estimated that there will be problems with uranium supply in the future. Nuclear reactors in the European Union produce around 2,500 tons of nuclear spent fuel per year (The European Technical Working Group on ADS, 2001; Biarrotte et al., 2009; Bouly et al., 2009). Nuclear spent fuel from fission reactors contains uranium (about $95 \mathrm{wt} \%$ ), plutonium ( $0.9 \mathrm{wt}$ $\%), \mathrm{MA} ; \mathrm{Np}, \mathrm{Am}$, and $\mathrm{Cm}(0.1 \mathrm{wt} \%)$, and fission products (4 wt\%). Nuclear spent fuel is considered to be a good energy source for existing reactors and is stored as nuclear waste. However, nuclear spent fuel management is one of the major problems in the use of nuclear energy (Waris and Sekimoto, 2001; Warin, 2007; IAEA, 2009). In order to solve this problem, this spent fuels has high radiotoxicity should be converted into stable or short-lived isotopes by nuclear reactions (Fridstrom, 2010; Loberg, 2010; Loberg et al., 2010; Zakova and Wallenius, 2013; Kumari et al., 2020). This situation can be created naturally or artificially, such as through human intervention (Günay, 2016).

MA, which has a low rate of nuclear fuel spent, is the most dangerous radioactive waste for public health due to its long life and high level of radioactivity (Şahin et al., 2011). In addition, some of the Mas, such as ${ }^{242 \mathrm{~m}} \mathrm{Am}\left(\sigma_{\mathrm{f}}=5700\right.$ barns) (Pfennig et al., 2006), and ${ }^{245} \mathrm{Cm}\left(\sigma_{\mathrm{f}}=2,145\right.$ barns) (Pfennig et al., 1998), have high fission cross-sections with thermal neutrons, and this makes MAs very valuable fissile fuel alternatives for reactors. One tonne of spent nuclear fuel remaining from existing 


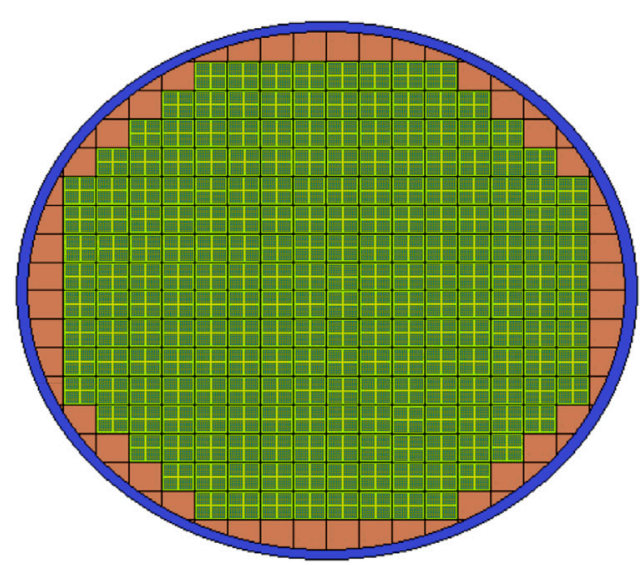

FIGURE 1 | The core design of the designed BWR system in MCNPX.

reactors (LWR) contains approximately $100 \mathrm{~g}$ of americium in MAs (Narbutt, 2020). The isotopes of americium have half-lives of ${ }^{241} \mathrm{Am}\left(t_{1 / 2}=432.2\right.$ years) (Audi et al., 2003), ${ }^{242} \mathrm{Am}\left(t_{1 / 2}=\right.$ $16 \mathrm{~h}),{ }^{242 \mathrm{~m}} \mathrm{Am}\left(\mathrm{t}_{1 / 2}=141\right.$ years $)$, and ${ }^{243} \mathrm{Am}\left(t_{1 / 2}=7370\right.$ years $)$ and $3.43 \mathrm{Ci} / \mathrm{g}$ for ${ }^{241} \mathrm{Am}, 808 \mathrm{Ci} / \mathrm{g}$ for ${ }^{242} \mathrm{Am}, 10.5 \mathrm{Ci} / \mathrm{g}$ for ${ }^{242 \mathrm{~m}} \mathrm{Am}, 0.199 \mathrm{Ci} / \mathrm{g}$ for ${ }^{243} \mathrm{Am}$ activities (Keith et al., 2004). For this reason, in this study, we aimed to use americium mixed fuels to reduce the amount of long-lived and radioactive americium in MAs.

The fuel cladding of nuclear reactors can crack as it is exposed to the corrosive effects and stresses of the fission products. Zr-2 (98\% Zr, 1.6\% Sn, 0.15\% Fe, 0.1\% Cr, 0.05\% Ni) (Nishino et al., 1996; Masterson, 2017), SiC (48.3\% Si, 51.7\% C) (Sauder et al., 2013), and VC (80.9\% V, 19.1\% C) were developed as fuel cladding in LWRs to solve this undesired situation in reactor life and energy production. $\mathrm{Zr}-2, \mathrm{SiC}$, and $\mathrm{VC}$ have outstanding properties of not spreading cracks throughout the cladding, irradiation stability, low stress levels, the ability to maintain their mechanical properties and chemical inactivity at high temperatures, and resistance to vapor oxidation (Williams et al., 1996; Edsinger and Murty, 2001; Korkut et al., 2016; Jha et al., 2019; Singh et al., 2019). In nuclear reactors, a low thermal neutron absorption cross-section is preferred to increase energy production. $\mathrm{Zr}-2, \mathrm{SiC}$, and $\mathrm{VC}$ have thermal neutron crosssections of 0.18 barn, 0.12 barn (Zhou and Feng, 2018), and 5.1 barn (Finley et al., 1960), respectively.

Experimental and theoretical studies have been conducted on nuclear reactor core and fuel assembly for nearly 50 years. In recent years, studies have focused especially on the recycling of MAs (OECD-NEA, 2013). Maldonado et al. (2010) investigated $\mathrm{MA}$ as burnable poison using americium and $\mathrm{UO}_{2}$ in the BWR fuel assembly. François et al. (2011) suggested a MOX fuel in which all fuel pins contained MA and plutonium in the BWR fuel groups. Masumi et al. (1995) suggested the use of a Mixed oxide (MOX) fuel assembly with MA in BWR.

The reuse of long-life MAs as a MOX fuel (such as $\mathrm{NpO}_{2}$, $\mathrm{AmO}_{2}$, and $\mathrm{CmO}_{2}$ ) and fluoride compounds (such as $\mathrm{NpF}_{3}$, $\mathrm{AmF}_{3}$, and $\mathrm{CmF}_{3}$ ) in nuclear reactors reduces both energy production and the burden of keeping them for many years

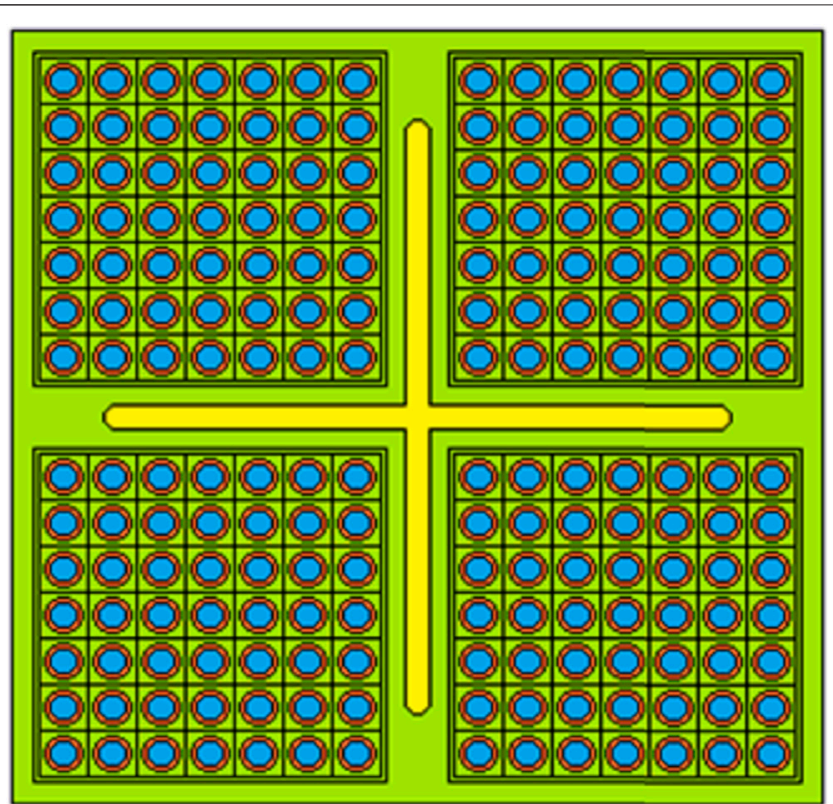

FIGURE 2|The square lattice in the core of the designed BWR system in MCNPX.

(IAEA, 2009; Lu et al., 2013; OECD-NEA, 2015; Van Rooijen et al., 2015; Dolan, 2017; Vigier et al., 2018). Technically, $\mathrm{AmO}_{2}$ is used as a source for alpha particles in a typical smoke detector (Kostecka, 2008). MOX and fluoride compound fuels provide cladding concepts compatible with cladding (such as $\mathrm{SiC}$ ) (Dolan, 2017). In this study, $\mathrm{AmO}_{2}$ and $\mathrm{AmF}_{3}$ fuels were used in the ranges of $0.02-0.1 \%$ as americium mixed fuels, and $\mathrm{Zr}-2, \mathrm{SiC}$, and $\mathrm{VC}$ were used as clad. In this study, neutronic calculations were made as $\mathrm{k}_{\mathrm{eff}}$, neutron flux, fission energy, heating, and depleted Am. The aim of this study is to investigate the effects of americium mixed fuels and clads on neutronic calculations in the designed BWR system. In the present study, the MCNPX2.7.0 Monte Carlo method and the ENDF/B-VII.0 nuclear data library were used for 3-D numerical calculations in the designed BWR system.

\section{MATERIALS AND METHODS}

\section{Geometry Description}

In this study, parameters of the Peach Bottom-2 nuclear power plant (Solis et al., 2001) were used in this BWR model. The designed BWR system is a cylinder, and the radius of the cylinder is $264.08 \mathrm{~cm}$. The total active core height is $365.76 \mathrm{~cm}$. The reactor core was divided into the square lattice $8 \times 8$ type with a constant pitch of $30.48 \mathrm{~cm}$. The core was surrounded by the reflector, which was graphite. The outboard side of the reflector was surrounded by SS316LN ferritic steel with a width of $5 \mathrm{~cm}$. The core design of the designed BWR system in this study is shown in Figure 1.

The core consists of 185 fuel assemblies surrounded by approximately 40 reflector assemblies. Every square lattice for 


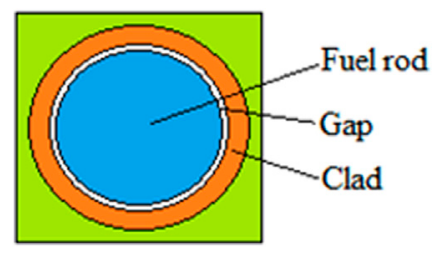

FIGURE 3 | Pin cell geometry of the designed BWR system in MCNPX.

the fuel rods was separated into four small square zones with a size of $13.40612 \mathrm{~cm}$. Every small square zone was divided into the small square lattices $7 \times 7$ type with a constant pitch of $1.94084 \mathrm{~cm}$. The square lattice (fuel assembly) in the core of the designed BWR system is shown in Figure 2.

It was put fuel pins in cylinder shape into the small square lattices. The fuel pins were created from the fuel rod, gap, and clad. It was made the fuel rod radius $0.60579 \mathrm{~cm}$ and the clad radius $0.71501 \mathrm{~cm}$ in the fuel pins. The gap had a width of $0.01524 \mathrm{~cm}$ in between the fuel rod and the clad. The pin cell geometry in the small square lattice of the designed BWR system is shown in Figure 3 (Günay et al., 2015).

A total of 49 fuel rods were placed inside every small square lattice with 196 fuel rods inside every square lattice. Thus, 36,260 fuel rods were put into the designed BWR system. The control rods provided reactivity control was put inside the cruciform in between four of the small square lattices. The blade radius of the control rod was $0.39624 \mathrm{~cm}$, and the blade half length was $11.98626 \mathrm{~cm}$. The absorber pins were made in cylinder shape into the cruciform (Figure 2). The absorber pins were used with a $0.23876 \mathrm{~cm}$ radius. A total of 185 cruciforms were used in the designed BWR system. In every cruciform, 84 absorber pins were used (21 per wing). Thus, 15,540 absorber pins were used in the designed BWR system.

Around $0.02-0.1 \% \mathrm{AmO}_{2}$ and $\mathrm{AmF}_{3}$ was used in the fuel rods, and $\mathrm{Zr}-2, \mathrm{SiC}$, and $\mathrm{VC}$ were used as the clad. In the cruciform, Type-304 stainless steel was used as the structural material. $\mathrm{H}_{2} \mathrm{O}$ was used as a coolant in the designed BWR system. The control rods were filled by $\mathrm{B}_{4} \mathrm{C}$.

\section{Numerical Calculations}

Nuclear data for reactor simulation are required. Nuclear data are obtained by experimental, theoretical, and Evaluated Nuclear Data Files (ENDFs). ENDF has been formed by compiling experimental data and calculations from different countries. ENDF is used with model calculations to make the reactor simulation (Şarer et al., 2009; Günay, 2013; Günay, 2015; Kabach et al., 2019; Wooten, 2019; Wan et al., 2020).

The Monte Carlo method (Pelowitz, 2011; Pelowitz et al., 2011) was developed for reactor simulation and modeling, many physical problems of deterministic methods, and threedimensional complex configurations of materials. The MCNPX (MCNP eXtended) (Waters, 2002) transport code from the Monte Carlo method examines neutron, proton, and photonuclear interactions using cross-section libraries from ENDF/B. The process of neutron transport should be investigated to determine the neutron distribution in the reactor. For this purpose, the Boltzmann equation is commonly used for neutronic calculations in a reactor.

$$
\begin{aligned}
\frac{1}{v} & \frac{\partial}{\partial t} \phi(r, \Omega, E, t)+\Omega \cdot \nabla \phi(r, \Omega, E, t) \\
& +\sum t(r, E, t) \phi(r, \Omega, E, t) \\
& =q(r, \Omega, E, t)
\end{aligned}
$$

$\frac{1}{\gamma} \frac{\partial}{\partial t} \phi(r, \Omega, E, t)=$ Change of neutron flux in unit time, $\Omega . \nabla \phi(r, \Omega, E, t)=$ Neutron loss because of convection, $\sum t(r, E, t) \phi(r, \Omega, E, t)=$ Neutron loss because of nuclear reactions.

Terms in Eq. 1 for $q(r, \Omega, E, t)$ can be defined as follows [Eq. 2]:

$$
\begin{aligned}
q(r, \Omega, E, t)= & \int_{0}^{\infty} d E_{l} \int_{4 \pi} d \Omega_{l} \sum\left(r, \Omega_{l} \rightarrow E \Omega_{l} \rightarrow \Omega\right) \phi\left(r \Omega, E_{l}, t_{l}\right) \\
& +S(r, \Omega, E, t)
\end{aligned}
$$

$\int_{0}^{\infty} d E^{\prime} \int 4 \pi d \Omega \sum\left(r, E^{\prime} \rightarrow E, \Omega^{\prime} \rightarrow \Omega\right) \phi\left(r, \Omega^{\prime}, E^{\prime}, t\right)$

Contribution of neutrons on neutron flux due to scattering. $S(r, \Omega, E, t)=$ Contribution of neutron source independent on the neutron flux

In this study, the 3-D modeling of the reactor core and fuel assembly into the designed BWR system was performed by using the ENDF/B-VII.0 (Chadwick et al., 2006) nuclear data library and MCNPX-2.7.0 Monte Carlo method to solve the Boltzmann Eqs 1, 2. The BWR system was designed with MCNPX-2.7.0 and was operated for $2000 \mathrm{MW}_{\text {th }}$ thermal power output and $1.10^{5}$ particle history.

\section{RESULTS}

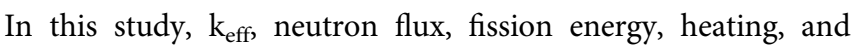
depleted Am neutronic values were calculated by using $\mathrm{Zr}-2$, $\mathrm{SiC}$, and $\mathrm{VC}$ as clad and $\mathrm{AmO}_{2}$ and $\mathrm{AmF}_{3}$ at the rate of $0.02-0.1 \%$ as fuel.

The effective neutron multiplication factor $\left(\mathrm{k}_{\mathrm{eff}}\right)$ is important for the critical status effective in determining the contribution of nuclear reactions to neutron multiplication of a nuclear reactor. $\mathrm{k}_{\text {eff }}$ [Eq. 3] is defined as the net increase in the number of neutrons from one generation to the next. $\mathrm{k}_{\mathrm{eff}}=1$ is the desired critical operating mode of a reactor. If $\mathrm{k}_{\text {eff }}<1$, the number of neutrons will decrease exponentially. If $\mathrm{k}_{\mathrm{eff}}>1$, the number of neutrons will increase exponentially, which will be dangerous to operate the reactor (Duderstadt and Hamilton, 1976; Ouahdani et al., 2018).

\section{$\mathbf{k}_{\mathrm{eff}}=\frac{(\text { number of neutrons generated in the next generation })}{(\text { number of neutrons generated in a generation })}$}

Figure 4 shows the $\mathrm{k}_{\text {eff }}$ value for $\mathrm{AmO}_{2}, \mathrm{AmF}_{3}$ fuels at $0.02-0.1 \%$ rates, and $\mathrm{Zr}-2, \mathrm{SiC}, \mathrm{VC}$ clads. Figure 4 shows that the $\mathrm{k}_{\text {eff }}$ value increases with the increase in the rates of $\mathrm{AmO}_{2}$ and 


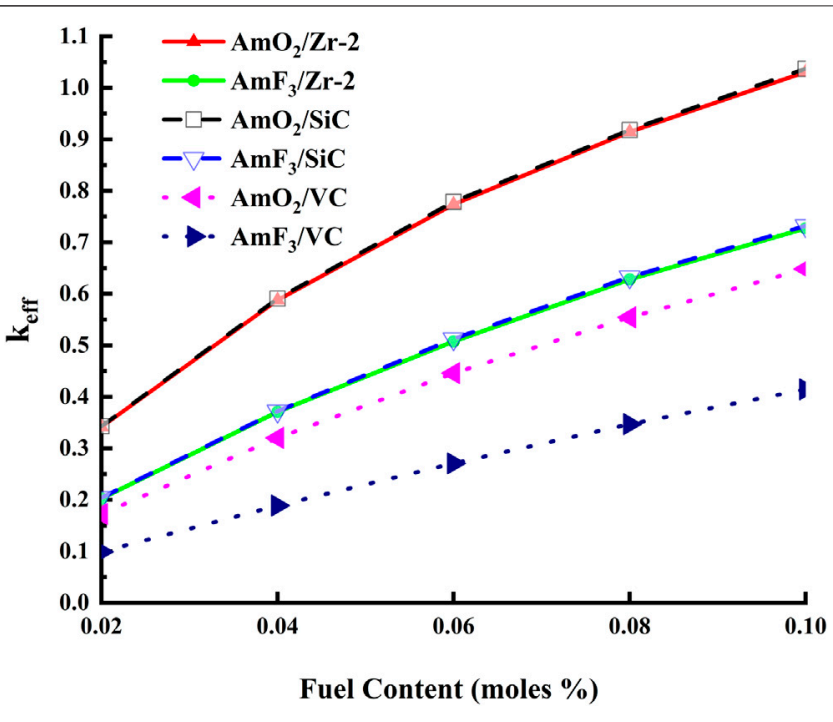

FIGURE 4 | The $\mathrm{k}_{\text {eff }}$ values for $\mathrm{Zr}-2, \mathrm{SiC}$, and VC clads, the fuel components $\mathrm{AmO}_{2}$ and $\mathrm{AmF}_{3}$ in the BWR system.

$\mathrm{AmF}_{3}$ fuels. $\mathrm{SiC}(\sigma=0.12 \mathrm{~b})$ contributes more to $\mathrm{k}_{\text {eff }}$ as it captures less thermal neutrons than $\mathrm{Zr}-2(\sigma=0.18 \mathrm{~b})$ and $\mathrm{VC}(\sigma=5.1$ barn). In a nuclear reactor, $\mathrm{k}_{\text {eff }}$ must be greater than 1 for its power to reach its maximum value from zero during start-up (Şahin and Şarer, 2019). But, the effective multiplication constant must $k_{\text {eff }} \leq 1$ with the help of control rods throughout the operation of the reactor to avoid the critical accident. As a result, it is seen that this reactor design for 0.08-0.1\% $\mathrm{AmO}_{2}$ fuel, $\mathrm{SiC}$ clad $\left(\mathrm{k}_{\mathrm{eff}}=0.918-1.037\right)$, and $\mathrm{Zr}-2$ clad $\left(\mathrm{k}_{\mathrm{eff}}=\right.$ 0.914-1.031) reaches the desired critical operating mode. It is also seen that $\mathrm{k}_{\text {eff }}$ is very small in $\mathrm{VC}$ clad for $\mathrm{AmO}_{2}$ and $\mathrm{AmF}_{3}$ fuels at $0.02-0.1 \%$ rates.

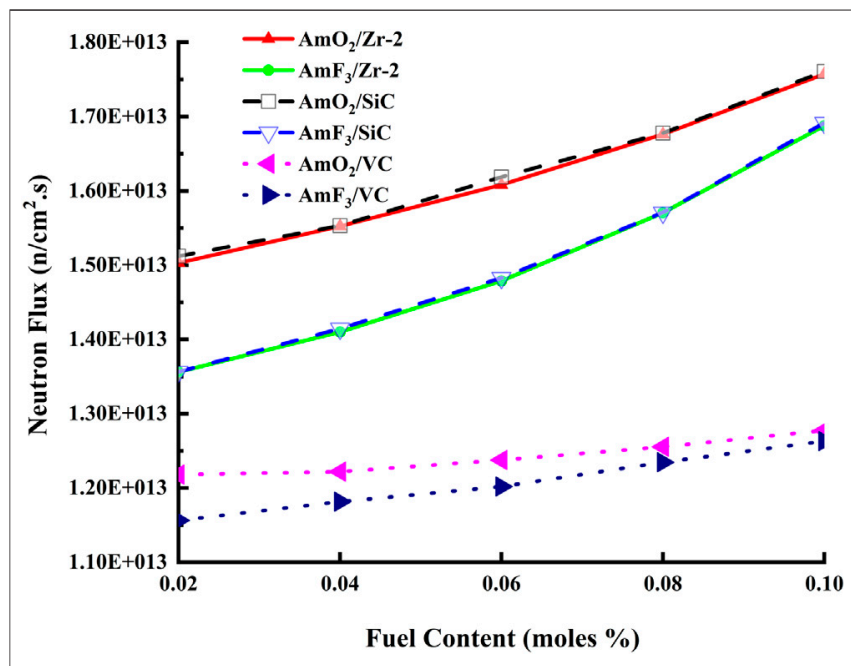

FIGURE 5 | The neutron flux values for $\mathrm{Zr}-2$, SiC, and VC clads, the fuel components $\mathrm{AmO}_{2}$ and $\mathrm{AmF}_{3}$ in the BWR system.

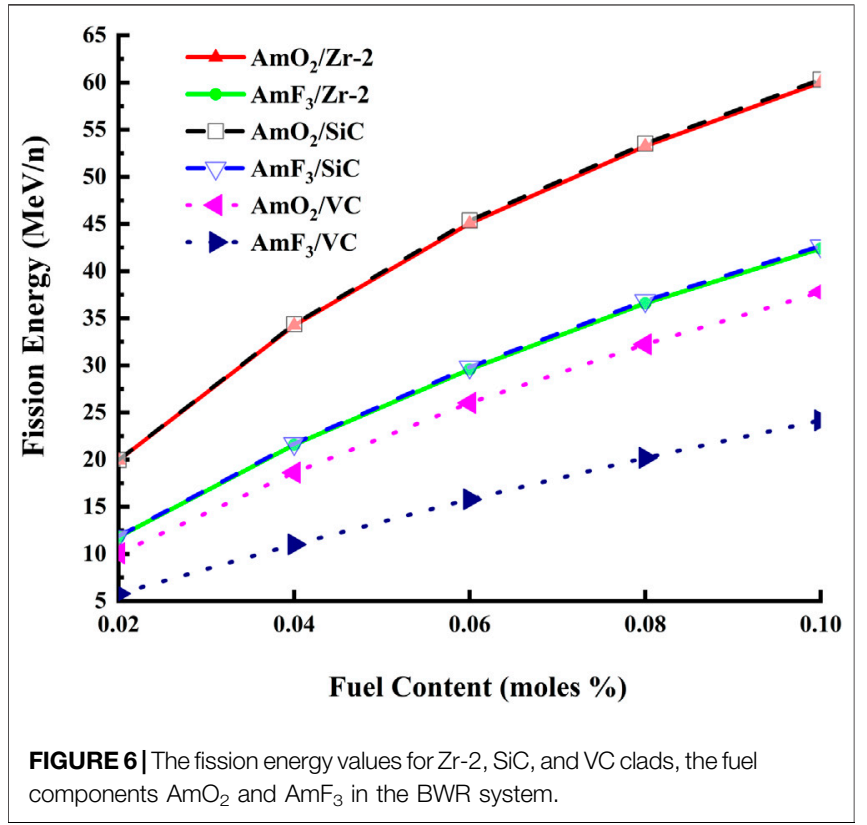

Figure 5 shows the neutron flux value for $\mathrm{AmO}_{2}$ and $\mathrm{AmF}_{3}$ fuels at $0.02-0.1 \%$ rates and $\mathrm{Zr}-2, \mathrm{SiC}$, and VC clads. Neutron flux distribution for a nuclear reactor is an effective parameter for neutronic calculations as fission energy, heating, and fissile fuel production. Neutron flux is the total length traveled by neutrons per unit time and volume (Stamm'ler and Abbate, 1983). In this study, in the BWR system simulation designed with MCNPX2.7.0, which F4 tally was used to calculate the neutron flux distribution by track-length estimates of the total cell flux. Figure 5 shows that the neutron flux value increases with the increase in the rates of $\mathrm{AmO}_{2}$ and $\mathrm{AmF}_{3}$ fuels. Figure 5 (for $\mathrm{SiC}$ captures less thermal neutrons than $\mathrm{Zr}-2$ and $\mathrm{VC}$ ) shows the highest neutron flux $\left(1.7609 .10^{13} \mathrm{n} / \mathrm{cm} 2 . \mathrm{s}\right)$ result from $0.1 \%$ $\mathrm{AmO}_{2}$ fuel for $\mathrm{SiC}$ clad and the lowest neutron flux $\left(1.1564 .10^{13} \mathrm{n} / \mathrm{cm} 2 . \mathrm{s}\right)$ result from $0.02 \% \mathrm{AmF}_{3}$ fuel for $\mathrm{VC}$ clad.

Figure 6 shows the fission energy values for $\mathrm{AmO}_{2}$ and $\mathrm{AmF}_{3}$ fuels at $0.02-0.1 \%$ rates and $\mathrm{Zr}-2, \mathrm{SiC}$, and $\mathrm{VC}$ clads in the designed BWR system. Fission energy released by the fission reaction consists of various energy modes, such as kinetic energy from fission products and fission neutrons, fast gamma rays, and energy from subsequent neutron capture. The fission energy in this regard is an important parameter for neutronic calculations of a nuclear reactor (Günay and Kasap, 2014; Liu et al., 2019). In this study, the F7 tally was used to calculate fission energy in the BWR system designed with MCNPX-2.7.0. Figure 6 shows that the fission energy value increases with the increase in the rates of $\mathrm{AmO}_{2}$ and $\mathrm{AmF}_{3}$ fuels. In addition, since the thermal neutron cross-section of $\mathrm{SiC}$ is less than $\mathrm{Zr}-2$ and $\mathrm{VC}$, more thermal neutrons in $\mathrm{SiC}$ contributed to fission energy production. As a result, it was seen in Figure 6 that the highest fission energy $(60.32 \mathrm{MeV} / \mathrm{n})$ from $0.1 \% \mathrm{AmO}_{2}$ fuel for $\mathrm{SiC}$ clad and the lowest fission energy $\left(5.78 \mathrm{MeV} / \mathrm{n}\right.$ ) from $0.02 \% \mathrm{AmF}_{3}$ fuel for $\mathrm{VC}$ clad.

Figure 7 shows the heating value in the relevant regions of the designed BWR system for the rates of $\mathrm{AmO}_{2}$ and $\mathrm{AmF}_{3}$ fuels, and 


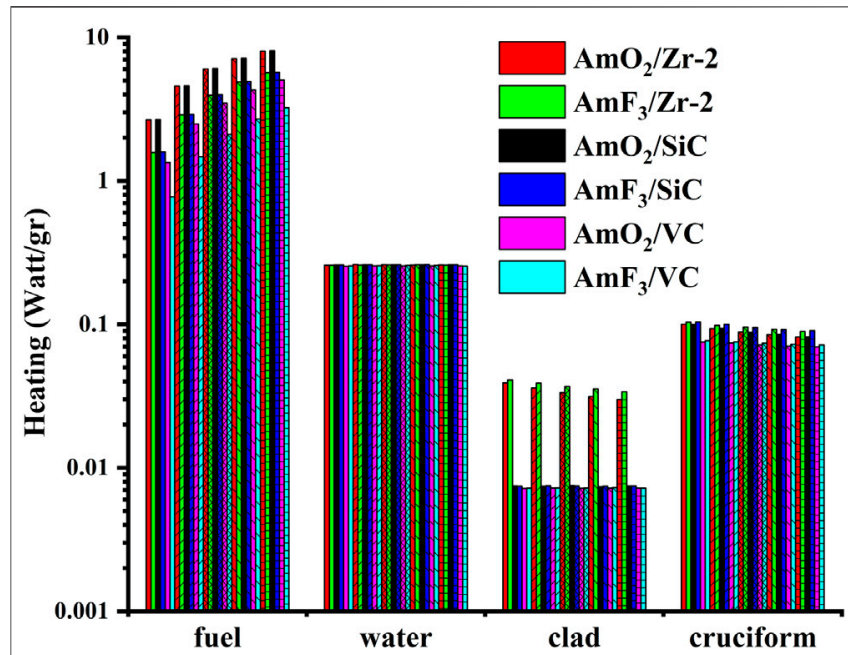

FIGURE 7 | The contribution of each zone to the heating for $\mathrm{Zr}-2, \mathrm{SiC}$, and $\mathrm{VC}$ clads, the fuel components $\mathrm{AmO}_{2}$ and $\mathrm{AmF}_{3}$ ( $0.02 \%, 0.04 \%, 0.06 \%$, $0.08 \%, 0.1 \%$ ) in the BWR system.

$\mathrm{Zr}-2, \mathrm{SiC}$, and VC clads. In addition, Table $\mathbf{1}$ shows the integrated heating for $\mathrm{Zr}-2$, SiC, and VC clads, the fuel components $\mathrm{AmO}_{2}$ and $\mathrm{AmF}_{3}$ in the BWR system. The F6 tally was used to calculate the heating by track-length estimates of the total cell heating, in this BWR system. Heating is produced through neutron flux, fission, and other reactions. Most of the fission energy released in the fuel region of a nuclear reactor turns into heating. Therefore, the neutron flux in the fuel region is more intense than the other regions for fission reaction occurs in the americium-mixed fuel rods in the fuel region of the designed BWR system. Hence, Figure 7 shows that the heating value in the fuel region is higher than the other regions. It was seen in Figure 7 that the heating value increased with the increase of fuel rates in the fuel region, and the $\mathrm{AmO}_{2}$ heating value was higher than $\mathrm{AmF}_{3}$ for $\mathrm{Zr}-2, \mathrm{SiC}$, and VC clads. In Figure 7 for the fuel region, it is seen that the highest contribution to heating comes from $0.1 \% \mathrm{AmO}_{2}$ with values of $8.0392 \mathrm{Watt} / \mathrm{gr}$ for $\mathrm{Zr}-2$, 8.0782 Watt/gr for $\mathrm{SiC}$, and $5.0597 \mathrm{Watt} / g r$ for VC, while the lowest contribution to heating comes from $0.02 \% \mathrm{AmF}_{3}$ with values of $1.5815 \mathrm{Watt} / \mathrm{gr}$ for $\mathrm{Zr}-2$, $1.5938 \mathrm{Watt} / \mathrm{gr}$ for $\mathrm{SiC}$ and $0.7738 \mathrm{Watt} / \mathrm{gr}$ for VC. As a result, the highest heating value in the fuel region was obtained from $0.1 \%$ $\mathrm{AmO}_{2}$ fuel content and $\mathrm{SiC}$ clad. A small heat release will occur through neutron and $\gamma$-ray radiation in the coolant around the

TABLE 1 | The integrated heating (Watt/gr) for Zr-2, SiC, and VC clads, the fuel components $\mathrm{AmO}_{2}$ and $\mathrm{AmF}_{3}$ in the BWR system.

\begin{tabular}{|c|c|c|c|c|c|c|}
\hline \multirow[t]{2}{*}{ moles $\%$} & \multicolumn{2}{|c|}{$\mathrm{Zr}-2$} & \multicolumn{2}{|c|}{ SiC } & \multicolumn{2}{|c|}{ VC } \\
\hline & $\mathrm{AmO}_{2}$ & $\mathrm{AmF}_{3}$ & $\mathrm{AmO}_{2}$ & $\mathrm{AmF}_{3}$ & $\mathrm{AmO}_{2}$ & $\mathrm{AmF}_{3}$ \\
\hline 0.02 & 3.041 & 1.966 & 3.069 & 1.985 & 1.683 & 1.113 \\
\hline 0.04 & 4.965 & 3.275 & 4.978 & 3.289 & 2.833 & 1.813 \\
\hline 0.06 & 6.419 & 4.354 & 6.434 & 4.358 & 3.818 & 2.453 \\
\hline 0.08 & 7.509 & 5.289 & 7.523 & 5.298 & 4.649 & 3.043 \\
\hline 0.1 & 8.411 & 6.060 & 8.428 & 6.073 & 5.392 & 3.571 \\
\hline
\end{tabular}

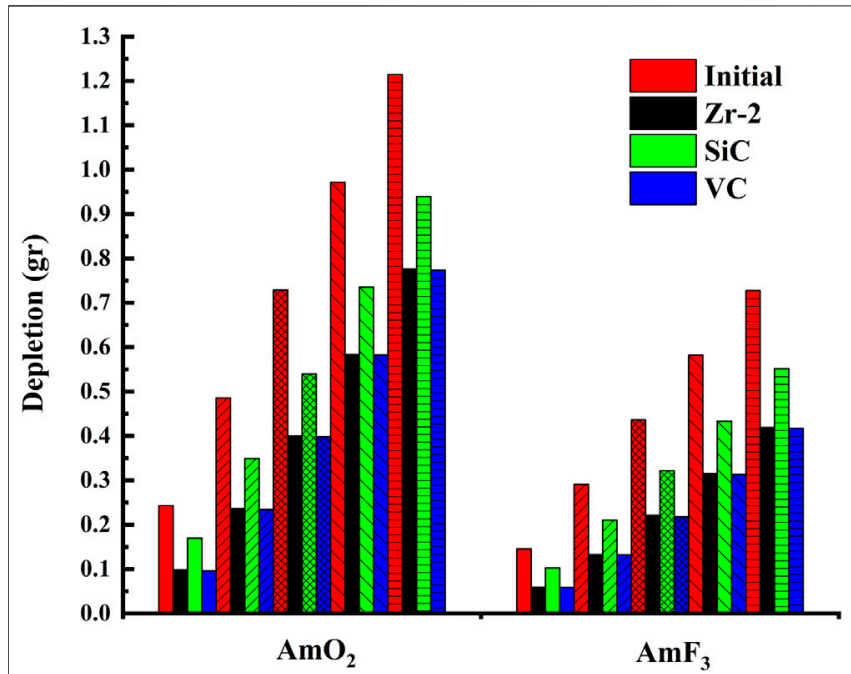

FIGURE 8 | The depleted Am values for $\mathrm{Zr}-2, \mathrm{SiC}$, and VC clads, the fuel components $\mathrm{AmO}_{2}$ and $\mathrm{AmF}_{3}$ ( $\left.0.02 \%, 0.04 \%, 0.06 \%, 0.08 \%, 0.1 \%\right)$ in the BWR system (the red color indicates the initial Am amount before the fuel is discharged; the black, green and blue colors indicate the depleted Am amount after the fuel is discharged for the clads).

fuel rods (Şarer et al., 2013; Şahin et al., 2016). Figure 7 shows that the heating value in the coolant region (water) around the fuel rods increased slightly with the increase of fuel rates. When this increase is examined for the water region in Figure 7, we can see that the highest contribution $(0.2614 \mathrm{Watt} / \mathrm{gr})$ to heating comes from $0.1 \% \mathrm{AmO}_{2}$ and $\mathrm{SiC}$ clad, and the lowest contribution (0.2539 Watt/gr) comes from $0.02 \% \mathrm{AmF}_{3}$ and $\mathrm{VC}$ clad. In Figure 7, it is seen that the heating values in the clad and cruciform region decreased with the increase of fuel rates for $\mathrm{Zr}-2, \mathrm{SiC}$, and VC clads. It was seen in Figure 7 that the greatest contribution to the heating value comes from the fuel region and the smallest contribution comes from the clad region. It was observed in Table 1 that the integrated heating value increased due to the increase in the fission reaction with increasing fuel rates for $\mathrm{Zr}-2, \mathrm{SiC}$, and $\mathrm{VC}$ clads. It was seen in Table $\mathbf{1}$ that the heating values for $\mathrm{Zr}-2$ and $\mathrm{SiC}$ clads of $\mathrm{AmO}_{2}$ fuel and heating values for $\mathrm{Zr}-2$ and $\mathrm{SiC}$ clads of $\mathrm{AmF}_{3}$ fuel are similar results because of the similar thermal neutron cross sections of $\mathrm{Zr}-2$ and $\mathrm{SiC}$ clads. But $\mathrm{VC}$ contributes less to the integrated heating value (both $\mathrm{AmO}_{2}$ and $\mathrm{AmF}_{3}$ fuel), as it captures more thermal neutrons than $\mathrm{Zr}-2$ and $\mathrm{SiC}$. As a result, it was seen in Table 1 that the smallest contribution to the integrated heating value comes from $0.02 \% \mathrm{AmF}_{3}$ fuel for $\mathrm{VC}$ clad with $1.113 \mathrm{Watt} / \mathrm{gr}$ and the greatest contribution to the integrated heating value comes from $0.1 \% \mathrm{AmO}_{2}$ fuel for $\mathrm{SiC}$ clad with 8.428 Watt/gr.

Figure 8 shows the amount of depleted $\mathrm{Am}$ for $\mathrm{AmO}_{2}$ and $\mathrm{AmF}_{3}$ fuels in $0.02-0.1 \%$ rates and $\mathrm{Zr}-2, \mathrm{SiC}$, and $\mathrm{VC}$ clads in the designed BWR system. Figure 8 shows that the depleted Am value increases with the increase in the rates of $\mathrm{AmO}_{2}$ and $\mathrm{AmF}_{3}$ fuels for $\mathrm{Zr}-2, \mathrm{SiC}$, and VC clads. In Figure $\mathbf{8}$ is seen that the amount of depleted $\mathrm{Am}$ is the highest for $0.1 \% \mathrm{AmO}_{2}$ and $\mathrm{AmF}_{3}$ fuels and the lowest for $0.02 \% \mathrm{AmO}_{2}$ and $\mathrm{AmF}_{3}$ fuels. The thermal neutron 
cross-section of $\mathrm{SiC}$ is less than $\mathrm{Zr}-2$ and VC. Thus, when using $\mathrm{SiC}$ cladding, more thermal neutron contributes to the amount of depleted Am. As a result, it was seen in Figure 8 that the highest depleted Am (0.939 gr) from $0.1 \% \mathrm{AmO}_{2}$ fuel for $\mathrm{SiC}$ clad and the lowest depleted Am (0.059 gr) from $0.02 \% \mathrm{AmF}_{3}$ fuel for VC clad after the fuel was discharged.

\section{DISCUSSION}

In this study, a BWR system in $8 \times 8$ type square lattice was designed by using MCNPX-2.7.0 Monte Carlo method for modeling, ENDF/B-VII.0 nuclear data library for neutronic calculations, $\mathrm{AmO}_{2}$ and $\mathrm{AmF}_{3}$ for fuel rods, $\mathrm{Zr}-2, \mathrm{SiC}$, and VC for clad. Neutronic calculations such as $\mathrm{k}_{\mathrm{eff}}$, neutron flux, fission energy, heating, and depleted Am were made for $0.02-0.1 \% \mathrm{AmO}_{2}$ and $\mathrm{AmF}_{3}$ fuels and $\mathrm{Zr}-2, \mathrm{SiC}$, and $\mathrm{VC}$ clads.

In the study, it was observed that $\mathrm{k}_{\mathrm{eff}}$, neutron flux, fission energy, heating, and depleted Am values increased with the increasing rates of Am mixed fuels in $\mathrm{Zr}-2, \mathrm{SiC}$, and $\mathrm{VC}$ clads. It was found that neutronic results calculated with $\mathrm{AmO} 2$ fuel and $\mathrm{SiC}$ clad were higher than $\mathrm{AmF}_{3}$ fuel and $\mathrm{Zr}-2$, VC clads. As a

\section{REFERENCES}

Audi, G., Bersillon, O., Blachot, J., and Wapstra, A. H. (2003). The NUBASE evaluation of nuclear and decay properties. Nucl. Phys. A. 729, 3-128. doi:10. 1016/j.nuclphysa.2003.11.001

Biarrotte, J. L., Bouly, F., Bousson, S., Junquera, T., Mueller, A. C., Olry, G., et al. (2009). "Accelerator R\&D for the European ADS demonstrator," in Proceedings of the 23rd particle accelerator conference (PAC09), Vancouver, Canada, May 4-8, 2009, 1-5.

Bouly, F., Biarrotte, J. L., Blache, P., Bousson, S., Commeaux, C., Duthil, P., et al. (2009). "Construction of a $700 \mathrm{MHz}$ prototypical cryomodule for the EUROTRANS ADS proton linear accelerator," in Proceedings of the 14th international conference on RF superconductivity (SRF2009), 20-25 September 2009 Berlin, Germany, 193-197.

Chadwick, M. B., Obložinský, P., Herman, M., Greene, N. M., McKnight, R. D., Smith, D. L., et al. (2006). ENDF/B-VII.0: next generation evaluated nuclear data library for nuclear science and technology. Nucl. Data Sheets. 107, 2931-3060. doi:10.1016/j.nds.2006.11.001

T. J. Dolan (Editor) (2017). Molten salt reactors and thorium energy. Karlsruhe: Woodhead Publishing Series in Energy.

Doligez, X., Bouneau, S., David, S., Ernoult, M., Zakari-Issoufou, A. A., Thiollière, N., et al. (2017). Fundamentals of reactor physics with a view to the (possible) futures of nuclear energy. C.R. Phys. 18, 372-380. doi:10.1016/j.crhy.2017. 10.004

Duderstadt, J. J., and Hamilton, L. J. (1976). Nuclear reactor analysis. 6th Edn. New York, NY: John Wiley \& Sons.

Edsinger, K., and Murty, K. L. (2001). LWR pellet-cladding interactions: materials solutions to SCC. JOM. 53, 9-13. doi:10.1007/s11837-001-0079-7

Finley, J. J., Korchynsky, M., and Sarian, S. (1960). “Columbium alloy clad uranium carbide fuel element”. United States Atomic Energy Commission. New York, NY: Union Carbide Metal Company), 31.

François, J. L., Guzmán, J. R., Campo, C. M., and Palomera, M. Á. (2011). Design and optimization of an equilibrium reload with MOX fuel with minor actinides, Prog. Nucl. Energ. 53, 566-570. doi:10.1016/j.pnucene.2010.08.008

Fridstrom, R. (2010). Response of the gamma TIP detectors in a nuclear boiling water reactor. UPTEC F10 042. ISSN: 1401-5757.

Günay, M. (2013). Investigation of radiation damage in structural material of APEX reactor by using Monte Carlo method. Ann. Nucl. Energ. 53, 59-63. doi:10.1016/j.anucene.2012.06.038 conclusion, considering the neutronic results obtained in this study, it is recommended to use $\mathrm{AmO}_{2}$ fuel and $\mathrm{SiC}$ clad in $\mathrm{BWR}$ reactor models.

\section{DATA AVAILABILITY STATEMENT}

The raw data supporting the conclusions of this article will be made available by the authors, without undue reservation.

\section{AUTHOR CONTRIBUTIONS}

The conceptualization and design of the work, data acquisition, analysis and interpretation of data, writing, reviewing, and editing were carried out by MD.

\section{ACKNOWLEDGMENTS}

This work was supported by İnönü University Scientific Research Projects Unit with the project number FBA-2020-2307.

Günay, M. (2015). The neutronic calculations for some fluids, libraries and structural materials in a hybrid reactor system. Kerntechnik. 80, 449-453. doi: $10.3139 / 124.110530$

Günay, M. (2016). Monte Carlo calculations of the nuclear effects of certain fluids in a hybrid reactor, Prog. Nucl. Energy. 86, 103-109, doi:10.1016/j.pnucene. 2015.10.017

Günay, M., Espinoza, V. H. S., and Travleev, A. (2015). The effect on neutronic calculations of certain alternative fuels in a boiling water reactor by using MCNPX Monte Carlo method. Acta Phys. Pol. A. 128, 110-112. doi:10.12693/ APhysPolA.128.B-110

Günay, M., and Kasap, H. (2014). Neutronic investigation of the application of certain plutonium-mixed fluids in a fusion-fission hybrid reactor. Ann. Nucl. Energy. 63, 432-436. doi:10.1016/j.anucene.2013.08.024

IAEA (2009). Status of minor actinide fuel development. Vienna: International Atomic Energy Agency. Nuclear Energy Series No. NF-T-4.6.

Jha, S. K., Dixit, S., Chetan, K., Vaibhaw, K., and Srivastava, D. (2019). Coextrusion of Zircaloy-2 and Zr-Sn alloy for double clad tube manufacturing: numerical simulation and experimental validation. J. Manuf. Process. 39, 18-25. doi:10.1016/j.jmapro.2019.01.048

Kabach, O., Chetaine, A., and Benchrif, A. (2019). Processing of JEFF-3.3 and ENDF/B-VIII.0 and testing with critical benchmark experiments and TRIGA Mark II research reactor using MCNPX. Appl. Radiat. Isot. 150, 146-156. doi:10.1016/j.apradiso.2019.05.015

Keith, S., Ingerman, L., McCartney, R. A., Chappell, L. L., Wohlers, D. W., Sage, G. W., et al. (2004). "Toxicological profile for americium," inChemical, physical, and radiological information. Atlanta, GA: ATSDR, 103-104.

Korkut, T., Kara, A., and Korkut, H. (2016). Effect of ultra high temperature ceramics as fuel cladding materials on the nuclear reactor performance by SERPENT Monte Carlo code. Kerntechnik. 81 (6), 599-608. doi:10.3139/124.110580

Kostecka, K. (2008). Americium-from discovery to the smoke detector and beyond. Bull. Hist. Chem. 33(2), 89-93.

Kumari, I., Kumar, B. V. R., and Khanna, A. (2020). A review on UREX processes for nuclear spent fuel reprocessing. Nucl. Eng. Des. 358, 110410. doi:10.1016/j. nucengdes.2019.110410

Liu, Y., Kochunas, B., Martin, W., and Downar, T. (2019). Delayed fission energy effect on LWR normal operation and transients. Ann. Nucl. Energy. 128, 84-93. doi:10.1016/j.anucene.2018.12.048

Loberg, J. (2010). Novel diagnostics and computational methods of neutron fluxes in boiling water reactors. Digital Comprehensive Summaries of Uppsala Dissertations from The Faculty of Science and Technology 715. 
Loberg, J., Österlund, M., Blomgren, J., and Bejmer, K. H. (2010). Neutron detection-based void monitoring in boiling water reactors. Nucl. Sci. Eng. 164, 69-79. doi:10.13182/NSE09-17

Lu, Y., Yang, Y., Zheng, F., Wang, B., and Zhang, P. (2013). Electronic, mechanical, and thermodynamic properties of americium dioxide. J. Nucl. Mater. 441, 411-420. doi:10.1016/j.jnucmat.2013.06.043

Maldonado, G. I., Galloway, J., and Hernandez, H. (2010). Recycling heterogeneous americium targets in a boiling water reactor. Ann. Nucl. Energy. 37, 256-264. doi:10.1016/j.anucene.2009.10.014

Masterson, R. E. (2017). Nuclear engineering fundamentals: a practical perspective. Boca Raton: CRP Press.

Masumi, R., Aoyama, M., and Yamashita, J. (1995). Minor actinide transmutation in BWR cores for multi-recycle operation with less minor actinide-to-fissile plutonium amount ratio. J. Nucl. Sci. .Technol. 32, 965-970. doi:10.1080/ 18811248.1995.9731804

Narbutt, J. (2020). "Solvent extraction for nuclear power," in Liquid-phase extraction. Editor C. F. Poole (Handbooks in separation science series, Massachusetts: Elsevier), 725-744.

Nishino, Y., Krauss, A. R., Lin, Y., and Gruen, D. M. (1996). Initial oxidation of zirconium and Zircaloy-2 with oxygen and water vapor at room temperature. J. Nucl. Mater. 228, 346-353. doi:10.1016/0022-3115(95)00194-8

OECD-NEA (2013). Minor actinide burning in thermal reactors. Paris: OECD.

OECD-NEA (2015). State-of-the-art report on multi-scale modelling of nuclear fuels. Paris: OECD.

Ouahdani, S. E., Boukhal, H., Erradi, L., Chakir, E., Azahra, M., Bardouni, T. E., et al. (2018). A temperature effect analysis of the KRITZ-1 benchmark based on keff decomposition and using the JENDL-4.0 and ENDF/B-VII.1 libraries. Prog. Nucl. Energy. 109, 121-129. doi:10.1016/j.pnucene.2018.07.012

D. B. Pelowitz (Editor) (2011). MCNPX user's manual, version 2.7.0. Los Alamos National Laboratory Report. LA-CP-11-00438.

Pelowitz, D. B., Joe, D. W., Jay, E. S., Michael, F. L., John, H. S., Michael, J. R., et al. (2011). MCNPX 2.7.0 extensions. Los Alamos National Laboratory Report. LAUR-11-02295.

Pfennig, G., Nebenius, H. K., and Eggebert, W. S. (1998). Karlsruher nuklidkarte chart of the nuclides. 6th Edn. Technik und Umweilt, Karlsruhe: Forschungszentrum Karlsruhe.

Pfennig, G., Nebenius, H. K., and Eggebert, W. S. (2006). Karlsruher nuklidkarte chart of the nuclides. 7th Edn. Technik und Umweilt, Karlsruhe: Forschungszentrum Karlsruhe.

Şahin, S., Khan, M. J., and Ahmed, R. (2011). Fissile fuel breeding and minor actinide transmutation in the life engine. Fusion Eng. Des. 86, 227-237. doi:10. 1016/j.fusengdes.2011.01.002

Şahin, S., Şarer, B., and Çelik, Y. (2016). Utilization of nuclear waste plutonium and thorium mixed fuel in candu reactors. Int. J. Energy Res. 40, 1901-1907. doi:10. 1002/er.3464

Şahin, S., and Şarer, B. (2019). Large- scale energy production with thorium in a typical heavy- water reactor using high-grade plutonium as driver fuel. Int. J. Energy Res. 43, 945-955. doi:10.1002/er.4335

Şarer, B., Aydın, A., Günay, M., Korkmaz, M. E., and Tel, E. (2009). Calculations of neutron-induced production cross-sections of ${ }^{180,182,183,184,186} \mathrm{~W}$ up to 20 MeV. Ann. Nucl. Energy. 36, 417-426. doi:10.1016/j.anucene.2008.11.025

Şarer, B., Şahin, S., Çelik, Y., and Günay, M. (2013). Evaluation of integral quantities in an accelerator driven system using different nuclear models implemented in the MCNPX Monte Carlo transport code. Ann. Nucl. Energy. 62, 382-389. doi:10.1016/j.anucene.2013.05.045

Sauder, C., Michaux, A., Loupias, G., and Braun, J. (2013). “Assessment of SiC/SiC cladding for LWRs," in LWR fuel performance meeting (top fuel), Charlotte, United States, September 15-19, 951-956.

Singh, G., Gorton, J., Schappel, D., Brown, N. R., Katoh, Y., Wirth, B. D., et al. (2019). Deformation analysis of SiC-SiC channel box for BWR applications. J. Nucl. Mater. 513, 71-85. doi:10.1016/j.jnucmat.2018.10.045

Solis, J., Ivanov, K. N., Sarikaya, B., Olson, A. M., and Hunt, K. W. (2001). Boiling water reactor turbine trip (TT) benchmark. Volume I. US nuclear regulatory commission. OECD nuclear energy agency. Paris, OECD Publishing, 1-66.

Stamm'ler, R. J. J., and Abbate, M. J. (1983). Methods of steady-state reactor physics in nuclear design. London, United Kingdom: Academic Press.

The European Technical Working Group on ADS (2001). A European roadmap for developing accelerator driven systems (ADS) for nuclear waste incineration. Roma.

Van Rooijen, W. F. G: ENEA., Shimazu, Y., and Yamano, N. (2015). Criticality uncertainty dependence on nuclear data library in fast molten salt reactors. Energy Proced. 71, 3-13. doi:10.1016/j.egypro.2014.11.849

Vigier, J. F., Freis, D., Pöml, P., Prieur, D., Lajarge, P., Gardeur, S., et al. (2018). Optimization of uranium-doped americium oxide synthesis for space application. Inorg. Chem. 57, 4317-4327. doi:10.1021/acs.inorgchem.7b03148

Wan, C., Zou, X., Cao, L., and Wu, H. (2020). Covariance comparisons between ENDF/B-VII.I and ENDF/B-VIII.0 with application for the UAM-LWR exercises. Ann. Nucl. Energy. 138, 107183. doi:10.1016/j.anucene.2019.107183

Warin, D. (2007). Status of the French research program on partitioning and transmutation. J. Nucl. Sci. Technol. 44, 410-414. doi:10.1080/18811248.2007.9711302

Waris, A., and Sekimoto, H. (2001). Characteristics of several equilibrium fuel cycles of PWR. J. Nucl. Sci. Technol. 38, 517-526. doi:10.1080/18811248.2001. 9715062

L. S. Waters (Editor) (2002). MCNPX user's manual, version 2.3.0. LA-UR-02-2607.

Williams, C. D., Marlowe, M. O., Adamson, R. B., Wisner, S. B., Rand, R. A., and Armijo, J. S. (1996). "Zircaloy-2 lined zirconium barrier fuel cladding," in Twelfth international symposium. 11-14 September 1995, Germany, ASTM STP. Vol. 1295, 676-694. doi:10.1520/STP16196S

Wooten, H. O. (2019). An application for streamlined and automated ENDF cross section analysis and visualization (EXSAN). Ann. Nucl. Energy. 129, 482-486. doi:10.1016/j.anucene.2019.01.053

Zakova, J., and Wallenius, J. (2013). Multirecycling of Pu, Am and $\mathrm{Cm}$ in BWR. Ann. Nucl. Energy. 58, 255-267. doi:10.1016/j.anucene.2013.03.024

Zhou, B., and Feng, K. (2018). Zr-Cu alloy filler metal for brazing SiC ceramic. RSC Adv. 8, 26251-26254. doi:10.1039/C8RA05480K

Conflict of Interest: The author declares that the research was conducted in the absence of any commercial or financial relationships that could be construed as a potential conflict of interest.

Copyright (c) 2021 Düz. This is an open-access article distributed under the terms of the Creative Commons Attribution License (CC BY). The use, distribution or reproduction in other forums is permitted, provided the original author(s) and the copyright owner(s) are credited and that the original publication in this journal is cited, in accordance with accepted academic practice. No use, distribution or reproduction is permitted which does not comply with these terms. 